\title{
Foreign Language Listening Anxiety among French Language Learners in Malaysia
}

Jenniesy Majunggi \& Hazlina Abdul Halim

To Link this Article: http://dx.doi.org/10.6007/IJARBSS/v11-i3/8596

DOI:10.6007/IJARBSS/v11-i3/8596

Received: 14 January 2021, Revised: 18 February 2021, Accepted: 01 March 2021

Published Online: 13 March 2021

In-Text Citation: (Majunggi \& Halim, 2021)

To Cite this Article: Majunggi, J., \& Halim, H. A. (2021). Foreign Language Listening Anxiety among French Language Learners in Malaysia. International Journal of Academic Research in Business and Social Sciences, 11(3), 226-242.

\section{Copyright: (c) 2021 The Author(s)}

Published by Human Resource Management Academic Research Society (www.hrmars.com)

This article is published under the Creative Commons Attribution (CC BY 4.0) license. Anyone may reproduce, distribute, translate and create derivative works of this article (for both commercial and non-commercial purposes), subject to full attribution to the original publication and authors. The full terms of this license may be seen at: http://creativecommons.org/licences/by/4.0/legalcode

Vol. 11, No. 3, 2021, Pg. 226 - 242

Full Terms \& Conditions of access and use can be found at http://hrmars.com/index.php/pages/detail/publication-ethics 


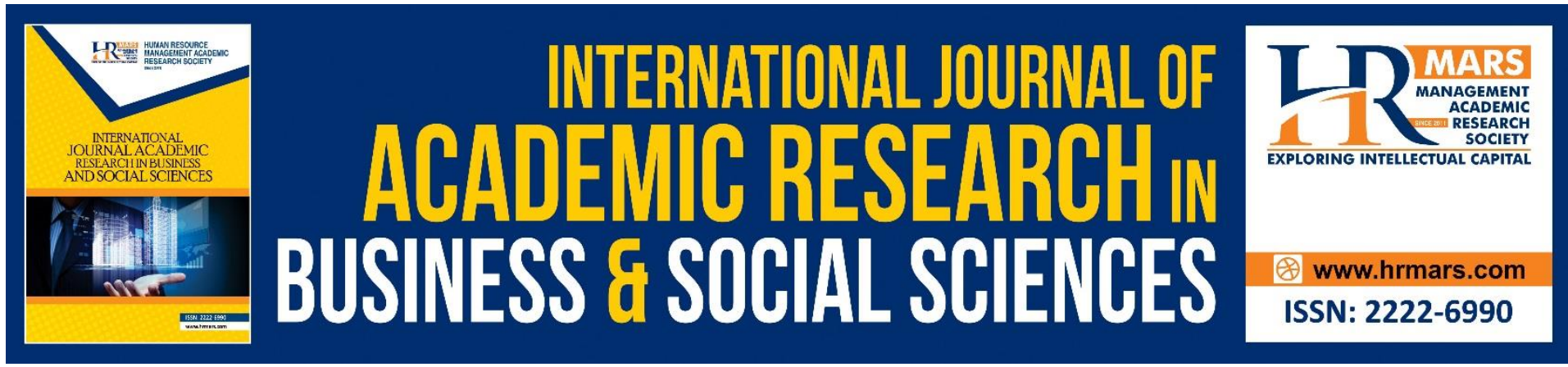

\title{
Foreign Language Listening Anxiety among French Language Learners in Malaysia
}

\author{
Jenniesy Majunggi \& Hazlina Abdul Halim \\ Faculty of Modern Languages And Communication, University Putra Malaysia \\ Email: mllej.majunggi@gmail.com, hazlina_ah@upm.edu.my
}

\begin{abstract}
Foreign Language Listening Anxiety (FLLA) has a considerable impact on students' foreign language learning achievements. The feeling of tension and apprehension while listening to a foreign language could be caused by various factors, namely the teachers, the learners themselves or even the classroom atmosphere (Pan, 2016). Using Kim's (2000) Foreign Language Listening Anxiety Survey (FLLAS), this study investigates whether French language students in Secondary Schools suffer from listening anxiety as well as the causes of their anxieties in listening comprehension. The FLLAS survey had been distributed to 36 SMK Elopura French language students. The survey's findings show that students experience a high level of anxiety in French language listening. This research will attempt to identify the learners' anxiety level and explain the cause that triggers their listening anxiety.

Keywords: Listening Comprehension, Listening Anxiety, Foreign Language Learning, French Language.
\end{abstract}

\section{Introduction}

Anxiety is possibly the strongest negative element of affective factors which influences language performance and therefore, frequently obstructs the learning process (Maclntyre \& Gardner, 1994; Hidayati et al., 2020; Xu, 2011). It is an affective factor that could prevent a learner from acquiring the maximum level in learning. Maclntyre and Gardner (1994) explained Foreign Language Anxiety (FLA) as "the feeling of tension and apprehension specifically associated with language context, including speaking, listening, and learning". This negative feeling of uneasiness, tension, nervousness, and frustration prevents students from performing at their best in the targeted language, thus hindering their success. The Malaysian Diplome d'études de la langue français (DELF) A1 examination results from 2015 to 2019 (appendix A) indicated that students taking this exam seemed to have listening comprehension difficulties. One of the reasons of their poor performance in listening comprehension is caused by their learning anxiety. Thus, this research on the student anxiety and listening comprehension is pertinent as a first step in finding a solution for the listening comprehension problem among French language learners in Malaysia. 


\section{Literature Review}

Foreign Language (FL) classroom anxiety is one of the specific anxiety-situations that has been extensively researched. Horwitz et al. (1986) listed three types of anxiety: communication apprehension, test anxiety and fear of negative evaluation. The communication apprehension explains learners' anxiety when they need to use the foreign language to communicate; test anxiety builds on the fear of failure during the test or examination, while the fear of negative evaluation implies that learners experience anxiety towards their counterpart's evaluation. Past researches showed that students could only perform at their best and actively participate in a low-anxiety classroom environment (Pan, 2016; Xu, 2011). The level of anxiety will eventually decrease as they become more proficient in the FL. In order to study a specific type of anxiety in foreign language acquisition, the Foreign Language Classroom Anxiety Scale (FLCAS) has been developed by Horwitz et al. (1986) which consists of 33 items. Saito et al. (1999) extended the FLCAS to include Foreign Language Reading Anxiety Scale (FLRAS) and Foreign Language Listening Anxiety (FLLA) was eventually proposed by Elkhafaifi in 2005. Since then, many researchers have come up with different scales. Elkhafaifi (2005) presented the 20 items Foreign Language Listening Anxiety Scale (FLLAS) and Kim (2000) invented the FLLAS with 33 items learners' listening anxiety assessment.

However, previous researches that are conducted in finding the effects of anxiety on listening comprehension deliver conflicting results. Some researchers actually believe that language anxiety can be beneficial to a student's performance (Alpert \& Haber, 1960; Scovel, 1978). Alpert and Haber (1960) research's finding are found to be contradictory to the general opinion due to the different anxiety measures used in the 1960s and ' 70 s, such as test-anxiety and facilitating-debilitating test. On the other hand, Razak et al. (2017) believes that listening anxiety had no significant effect on student performance, following a research conducted on Yemeni university students where they used their mother tongue in writing the answer to questions asked in a foreign language. The study further suggests that the use of a mother tongue in the classroom could eliminate language anxiety among students.

Nonetheless, a current quantitative research by Gebre and Wako (2017) and a qualitative research by Oteir and Abd Aziz (2017) shows that high anxiety will attribute to poor performances. The feeling of tension and apprehension during the learning process will negatively impacts a student's performance and learning achievement. Some research goes even further by looking into students' anxiety level according to their level of proficiency in the target language. Wang and Cha (2018) examined the FLLA scales on low proficiency Chinese learners in English Foreign Language (EFL) and suggested that listening anxiety is a negative predictor of student's performance, hence confirming the results of previous a research (Kim, 2002; Liu, 2016; Subekti, 2018; Wang \& Cha, 2019; Zheng \& Cheng, 2018). This result is also supported by Isrokah (2016) and in addition, she suggested that teachers should use the students' mother tongue when necessary to avoid anxiety-triggered blockages. This negative effect of anxiety on listening performance happens not only in low proficiency students but also among intermediate FL learners. In this regard, Ebadi and Oroji (2016) conclusion was also affirmative and shows a negative relationship between listening anxiety and learners' listening achievements. Nevertheless, low-proficient listeners are still believed to be more anxious than high-proficient learners (Chang, 2008; Kim, 2002; Wang \& Cha, 2019). It could be explained that this is due to the fact that high-proficient students invest an extensive amount of time to learn, compared to those that are low-proficient. Past researches indicate that anxiety is supposed to decrease as experience and proficiency increases (Elkhafaifi, 2005; Liu, 2016). 
Researchers further investigated the relationship between language anxiety and its effect on academic achievement based on gender and age differences. It is reported that foreign language anxiety in female students is higher than among male students. Those findings were also supported by previous researches on this topic (Cakici, 2016; Dordinejad \& Ahmadabad, 2014; Saeidi \& Khaliliaqdam, 2013; Shahnaz \& Bhatti, 2014). Scholars believe that genderbased differences in test anxiety can be explained by the higher emotional component that female learners experience, and their talent in learning a new language, compared to their male counterparts (Deffenbacher et al., 1980; Yan \& Horwitz, 2008). Some studies, however, suggest a higher anxiety among male learners as they are more concerned about making mistakes (Awan et al., 2010). Nevertheless, a considerable amount of research found that there is no gender effect on foreign language (Alshahrani \& Alandal, 2015; Aydın, 2013; Şakrak, 2009; Yamat \& Bidabadi, 2012). On the other note, the study on the relationship between anxiety and age reveals that younger learners are less anxious (Dewaele, 2002; P. D. MacIntyre \& Gardner, 1989). Recent research by Tosun (2018) on the possible relationship between anxiety and age, however, indicates no significant co-relation. The plausible reasoning for such result is because the participants of Tosun's research were attending the same course.

This diverse results on listening anxiety and its relation to age, level and gender may be caused by many factors. Previous researchers had conducted researches on the factors contributing to foreign language anxiety and they believe that teacher, leaners and classroom environment play an important role in students' anxiety levels (Pan, 2016; Vogely, 1998).

\section{Factor contributing Foreign Language Listening Anxiety}

The feeling of tension and apprehension during a learning process could be triggered by many factors. An early research by Vogely (1998) on factors contributing to the listening anxiety identified four causes of anxiety in listening comprehension. The causes determined were listening input characteristics, the process-related aspect of listening comprehension, the instructional factor, and the teachers' and learners' attributes. Furthermore, Pan (2016) managed to classify the list of causes into three categories: teacher and learner factor, listening material \& process factor, and the other factor. However, the factor contributing to anxiety in learning listening could be explained by the learners' internal and external factors.

The learners' lack of linguistic knowledge is one of the internal factors of anxiety while listening. The unfamiliar or difficult vocabulary or sentences used in the texts makes students find themselves unable to understand every detail of the message or even incapable to make sense of the listening material (Tahsildar \& Yusoff, 2014; Young, 1992). Furthermore, students' attitude and motivation also highly impacted learning anxiety. A lack of motivation and self-efficacy will only worsen the situation. A student who is determined to hold a higher learning self-expectation is less anxious than those who learn only to pass for the exam (Pan, 2016). The fear of failure in a listening test or an exam could cause a negative feeling of tension and apprehension in learning listening comprehension.

The external factor is related to teachers, learning material and process, as well as the learning environment. Teachers are accountable for choosing the listening materials and creating an appropriate learning atmosphere in the classroom to facilitate the students' learning process in listening comprehension exercises. The teacher is responsible for 
managing the already planned listening class with pre-listening, listening, and post-listening activities (Pan, 2016). In addition, the teacher's personality also highly influences the students' listening anxiety. Their attitudes, such as fun, humorous, outgoing, or severe towards the students does have a massive impact on the students' anxiety level. An easygoing teacher can create a warm and comfortable environment for language learning. The listening material used in the classroom also influences the students' listening anxiety. A rapid speech (Kim, 2000; Vogely, 1998), unfamiliar accent (Vogely, 1998), irregular pauses (Gilmore \& Vance, 2007) and complex lexical features (Flowerdew, 1994,p. 19) lead students to have fear and apprehension during the listening process. Finally, the environment factor such as lack of quality multimedia facilities and inadequate physical surroundings also contributes to high anxiety in the listening comprehension class.

In conclusion, research on listening anxiety and student's performance according to age, gender and level of proficiency discovered positive, negative and no significant result. Studies also indicate that listening anxiety is caused by many factors. Nevertheless, anxiety does affect the students' achievement and student performance in listening comprehension. As research shows that students could only perform better and participate actively in a lowanxiety classroom environment (Pan, 2016; Xu, 2011); therefore, addressing anxiety is becoming a priority in the classroom. Hence, more research ought to be conducted to investigate Malaysian French language learners' listening anxiety level and the cause of their listening anxiety to find the conclusive solution to appease this issue specifically in the French listening classroom exercise in Malaysia.

\section{Research Objectives}

This present research is conducted to answer the two research questions.

- Do French foreign language students suffer from listening anxiety?

- What is the factor that triggers French foreign language students listening anxiety?

\section{Methodology}

\section{Research design}

This study conducts a descriptive research design to determine French language learners' listening anxiety and the factor contribute to their anxiety. A survey questionnaire was distributed to 36 SMK Elopura French language learners to answer the research questions.

\section{Setting and Participants}

The 36 respondents have been studying the French language for two years at SMK Elopura. The 14 years old student participants have more than 50 hours of French language lesson. The respondents are chosen via a cluster sampling method where the participants are identified and included in the sample. In Sabah, there are only four active Secondary schools that offer the French language classroom: SM Sains Sabah, SM Sains Lahad Datu, SMK Sanzac and SMK Elopura. Among those four schools, SMK Elopura is selected to conduct the research for its practicality and time efficiency. They are selected as preliminary test subjects for an experimental research on the same group. The respondents distributed almost equally according to gender. Table 1 below shows the distribution of participants according to gender. 
Table 1:

Distribution of participants by gender

\begin{tabular}{ll}
\hline Gender & No \\
\hline Male & 19 \\
Female & 17 \\
\hline Total & 36 \\
\hline
\end{tabular}

\section{Instruments}

The study adopted the questionnaire developed by Kim (2000) comprises of 33 Likert scale items, divided into 3 themes: background knowledge ( 8 items), listening strategies ( 8 items) and listener's characteristics (17 items). Questions 1 to 8 relate to student background knowledge, 9 to 16 on listening strategies, and questions 17 to 33 on the listener's characteristics. The lower score will indicate lower anxiety while a higher score will indicate higher anxiety. The scale indicates a score continuum ranging from 1 "strongly disagree" to 5 "strongly agree". The anxiety score is derived by adding up the 33 items with a total score of 165. The questionnaire had been used to measure learners' anxiety levels in China (Wang \& Cha, 2019), in Iran (Ebadi \& Oroji, 2016), and among Malaysian University students (Tahsildar \& Yusoff, 2014). In this study, to answer the first research question, each student total score in FLLAS survey is analysed. For the second research question, the highest mean of all the 33 items is identified and examined. The FLLAS questionnaire is included in the Appendices section.

\section{Procedure}

The survey was distributed online as Malaysia was in the midst of a lockdown due to the COVID-19 pandemic outbreak at the time the survey was conducted. The participants of the research had been informed in advanced through a zoom classroom by the researcher. During the zoom session, the researcher explained the objective of the survey and described the elements present in the questionnaire. Upon receiving authorisation of university authorities, the survey was distributed to the teacher teaching the course and the students via WhatsApp group. Prior to answering the survey, a verbal and written instruction was given to the participants through WhatsApp voice and chat. The responses were analysed using SPSS software.

\section{Data Analysis}

The data collected through the online survey is analysed using the descriptive statistic method to determine the students' anxiety level and the factors causing the problem. The frequency of learner's anxiety identifies according to high, moderate, and low level. The Likert-scale score of each question is added up to quantify their anxiety level. The total score of 165 represents the highest level of anxiety while 33 represents the lowest level of anxiety. Finally, the mean obtained for each given item denotes the element that causes the participant's learning anxiety. The highest mean indicates the major source of student anxiety and viceversa.

\section{Result}

The findings indicate that participants have a high level of listening anxiety. Table 2 presents the three anxiety levels: high, moderate, and low level of anxiety that the 36 Secondary school French learners experience in French language listening classroom. The high anxiety level 
reflects on those participants who answered, "strongly agree" and "agree" in the survey, while the low anxiety learners answered the opposite: "strongly disagree" and "disagree". The moderate students are those who responded most question neutral.

Table 2:

Summary of participants' anxiety level

\begin{tabular}{|c|c|c|}
\hline Anxiety level & $\mathbf{N}$ & $\mathbf{\%}$ \\
\hline high & 34 & 94,4 \\
\hline moderate & - & - \\
\hline low & 2 & 5,6 \\
\hline & 36 & 100 \\
\hline
\end{tabular}

Research question 1: Do French foreign language students suffer listening anxiety?

In this study, each participant's total score ranges from 55 to 137.2 participants score from 55 to 62 and 34 participant score range from 97 to 137. According to the table, $94,4 \%$ of the students experience high anxiety levels, while only $5,6 \%$ suffer low anxiety. The highest mean recorded is 137 and the lowest is 55 .

This finding is parallel to the previous research of Annisa et al. (2020), Nasim Tahsildar and Shah Yusoff (2014), and Nurul Hidayati et al. (2020). Their research, however, is conducted in Malaysian and Indonesian universities. Based on this recent study, the feeling of tension and apprehension towards foreign language is not limited only to university level but also among secondary school students. Learners of French as foreign language in Sabah's Secondary Schools also suffer from high anxiety while conducting listening activities and listening tests or during general listening process.

Research question 2: What is the factor that triggers French foreign language students listening anxiety?

The factor that contributes to learners listening anxiety could be explained according to these three themes: background knowledge, listening strategies, and listener's character as being demonstrated in figure 1, 2 and 3. Figure 1 presents the anxiety in relation to the participant's background knowledge. 


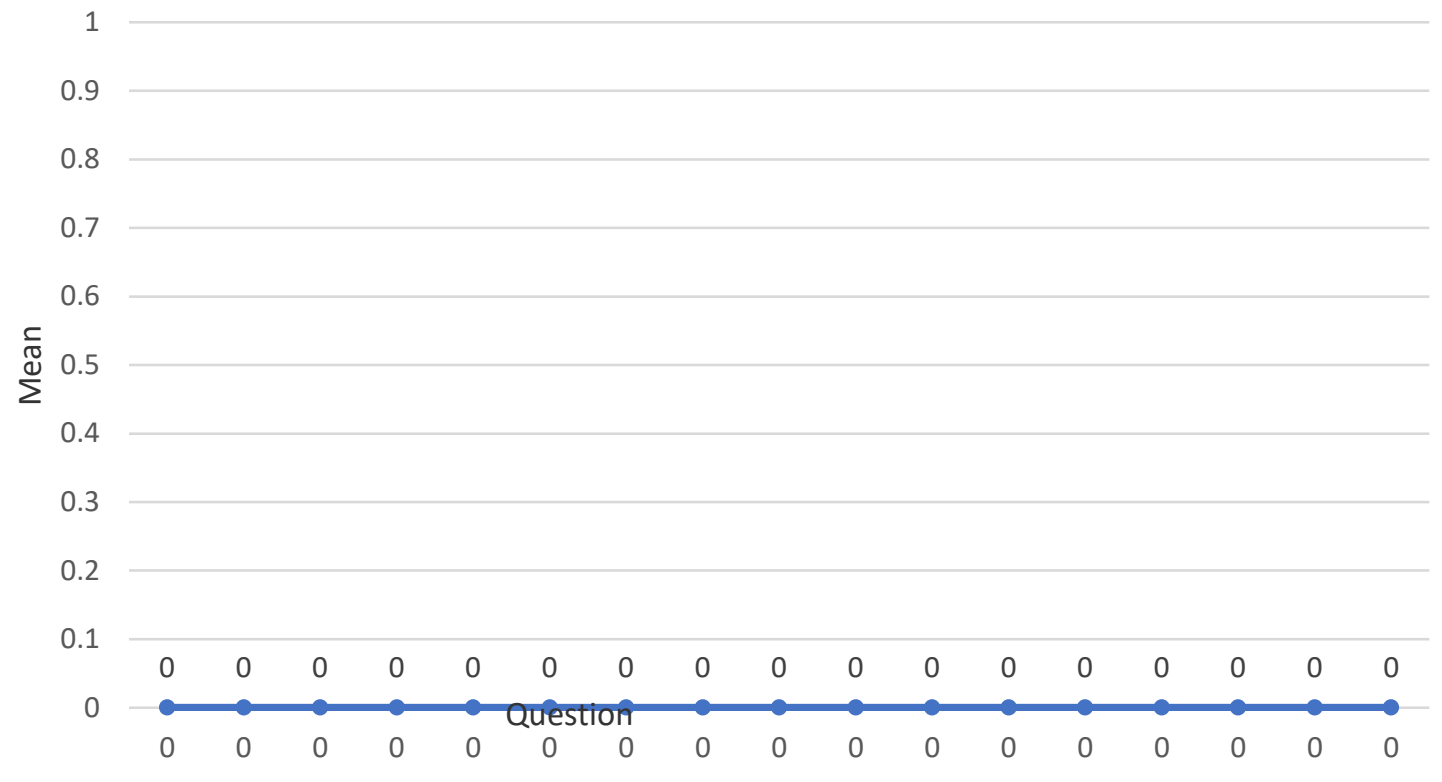

Figure 1: Mean score of students' opinions according to 5 Likert-scale on each FLLAS item.

The chart in figure 1 shows a high level of anxiety on Item 1,2,4,5,6,7 and 8 . The participants exhibit a moderate level of anxiety on question 3 , which is related to their ability to guess which parts they missed out on while listening to French sentences. The majority are also indecisive on their ability to guess the missing information during the listening process whereas $38.89 \%$ answered neutral for this item. On the contrary, the participants' highest level of anxiety expressed in question 5 projects their feelings and emotions when they do not understand every word. The majority of the participants, which consist of $47.22 \%$ and $38.89 \%$ strongly agree and agreed that they get nervous and confused when unable to comprehend every term heard during the listening test. In general, participants manifest their worry over the lack of background knowledge. They believe having adequate knowledge of vocabulary and topic addressed is important in listening. Buck (2001) expressed the importance of background knowledge to lessen students' anxiety in listening. Hence, teachers will need to reinvent their teaching methods in the listening classroom to focus on students' background knowledge of the task ahead before conducting the listening exercise. The listening classroom should consist of the three stages: pre-listening, while-listening and postlistening (Field, 2009,p. 316). By focusing on activating student background knowledge in the pre-listening stage, student's anxiety level could be reduced.

Figure 2 demonstrates the participants' level of anxiety related to the listening text itself and their listening strategies. 


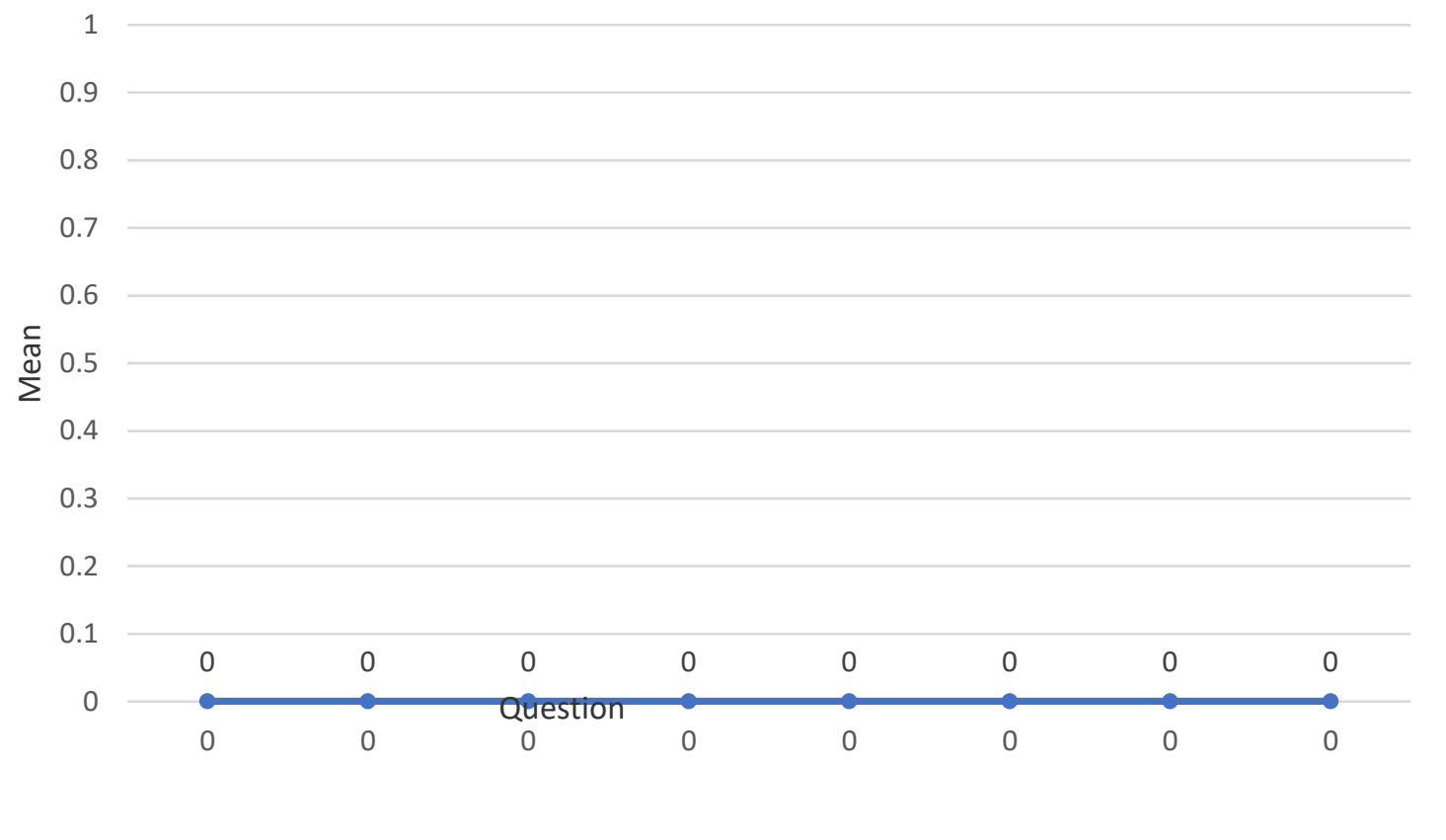

Figure 2: Mean score of students' opinions according to 5 Likert-scale on each FLLAS item.

Based on Figure 2, participants demonstrate a high level of anxiety in questions 9 and 11, followed by question 10 and 16 and question $12,13,14$, and 15 which demonstrate the same level of anxiety. Item 9 describes the amount of repetition of the listening passage during a test. $\mathbf{8 7 . 0 6 \%}$ of the participants strongly agree that they get nervous if a listening passage is read only once during the listening test. For item 11 , the result also indicates that $87.06 \%$ of participants strongly agree on having anxiety when a person speaks French very fast because they are worried that they might not understand all of it. In contrast, participants expressed a most moderate anxiety levels in questions 15 on their sentiment when listening to French without the text on hand. 20,59\% and $38.24 \%$ students strongly agreed and agreed while $17.5 \%$ and $23.53 \%$ participants answered neutral and disagree on the feeling of discomfort when a written text is not provided during French listening activity. This result suggests that listening strategies are an essential element in listening comprehension. Foreign language is a challenging skill and listening strategies are needed to increase student performance and encourage learners' autonomy (Chand, 2007). An effective listening strategy during listening could help students perform better under the stress of limited activity time, the rapidity of the text, and unpredictable topics. Students who can use metacognitive and cognitive strategies in listening activity most probably succeed better than those who do not use any strategies (Nor Zihan, 2011). Therefore, teachers need to train and teach the students to use listening strategies during listening comprehension lessons.

Lastly, Figure 3 exhibits the mean result of listening anxiety and listener's characteristic. This third part includes question 17 to 33. This set of questions inquire on students' attitude and behaviour towards listening activities. 


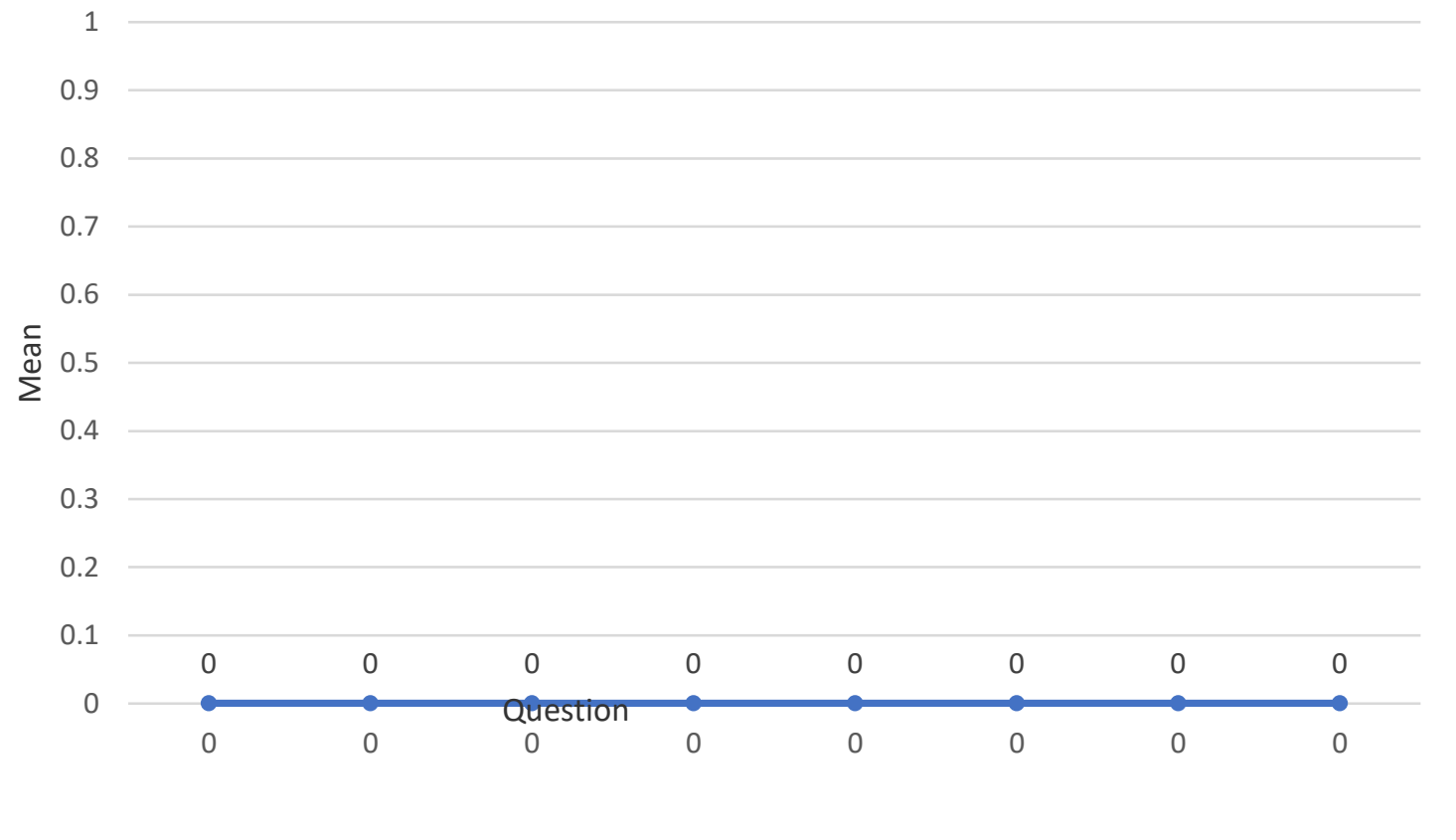

Figure 3: Mean score of students' opinions according to 5 Likert-scale on each FLLAS item.

According to Figure 3, Items 20,21,22,25,26,27,29,30,31 and 33 indicate a high level of listening anxiety, while on item 19, 23, 28 and 32 results describe a moderate anxiety-level among the survey participants. The highest anxiety level was demonstrated in question 23 on students' feeling when listening to French against their own pace. $45.95 \%$ of the participant strongly agreed and $27.03 \%$ agreed that they get worried when they could not listen to French at their own rhythm. On the opposite, the lowest mean result presented in question 19 discusses about participant's confidence when they are listening in French. $24.32 \%$ of the participants answered they agree, neutral and disagree for each scale, $21.62 \%$ for strongly disagree while $5.41 \%$ strongly agree on their level of assertiveness in French language listening. These results suggested that the lack of confidence, stress, nervousness, fear, and worry while listening to French language listening texts could contribute to high-anxiety levels. Maclntyre and Gardner (1989) suggested that shyness to communicate, fear of failure, and fear of others' negative evaluation are the major cause of anxiety in foreign language listening.

\section{Discussion}

The result indeed shows that the participants suffer high anxiety towards listening comprehension. Based on the findings, the study indicates that both external and internal factors influence students' anxiety level. Firstly, the students get worried, nervous, and confused due to their inadequate knowledge of vocabulary and topics. Learners are anxious about unfamiliar vocabulary or unfamiliar topics and fear they might miss important details. This study result is parallel to Young (1992); Annisa et al. (2020)previous research findings. Participants' self-confidence also correlates to the listening anxiety. Students with higher selfconfidence will have low anxiety, thus have higher achievement in listening (Basco \& Han, 2016).

Secondly, participants also find the listening comprehension process itself caused the listening anxiety. The fact that they can listen to the text only once and the lack of time to 
process all the details, such as the accent or facial expression makes the students more anxious. Buck (2001) identified these elements as factors causing the anxiety in listening comprehension. Listening is stressful when students have limited time and processing skills. Learners will find themselves trying to understand every word, thinking that would make them understand better. Arguably, understanding every word does not mean understanding the contexts they are listening to.

Finally, French language learners also associate their feelings of anxiety in listening to the external factors, such as not understanding the instruction given in French during the listening activity or inability to concentrate because of background noises. In factors such this, students need to practice the listening strategies to enhance their listening comprehension. Mohammadi Golchi (2012) believes that training students in metacognitive strategies could be handy in minimizing their anxiety in listening.

\section{Conclusion}

The study explores the listening anxiety among French language learners in Malaysia and the cause of their anxiety. The low results in listening comprehension in DELF saw the need to find the cause of the problem and eventually find its solution. Dörnyei (2005) suggested that language aptitude, motivation, learning strategies, anxiety, creativity, self-esteem, willingness to communicate and learners' beliefs are the characteristics that influence individual differences in language learning. He also mentions that the ambiguity of listening anxiety towards the learning performance needed to be addressed. Thus, this research is conducted to elucidate the Malaysian French language learners' anxiety level that and the cause of this anxiety.

The findings show that in general, Malaysian French language learners at SMK Elopura have a high anxiety level towards listening exercises and tests. The majority of the students feels the tension, worry and fear in listening to French language. In addition, the findings also confirm that the source of students' listening anxiety relates to internal and external factors. Learners fear that, their inability to understand everything and their inability to follow the listening activity according to their own pace, influences their understanding and ability to answer the question. Listening comprehension class has always been treated as a series of listening tests instead of teaching the necessary learning skills and strategies. Giving instructions in French also adding the stress that the students are facing in the listening lesson. Thus, Isrokah (2016), in her research on the correlation between foreign language listening anxiety and listening comprehension achievement, suggested the use of the Students' mother tongue to avoid blockage. When the students do not understand the instructions, it will make them anxious and make them unable to participate in the listening activity. Overall, the results show that the learners have a low self-confidence in French listening resulting from the internal and external anxiety factors.

This research also coincides with the Tahsildar and Yusoff (2014) on Malaysian university students' anxiety in second language listening. It is believed that Malaysian students feel the anxiety towards listening in a second and foreign language, either university or school level. The anxiety originated in the students' lack of knowledge input, lack of listening strategies and external factors such as teachers and physical surroundings. Certainly, it would be interesting to examine other circumstances such as listening external anxiety factor (teacher's 
role in the listening classroom, teaching pedagogy, etc.) that may also have massive influence in learners' listening anxiety. The teacher's teaching method and communication styles highly influence students' performance. The low-anxiety classroom environment will produce a better or good performance student. Therefore, it is important to find a suitable solution to appease learners' anxiety to succeed and perform better in listening comprehension.

The finding of this study hopes to create awareness among French language teachers on the importance of language anxiety in language learning. As anxiety influences students' performance in learning, teachers should create an anxiety-free environment to help them deal with their fear and eventually ease their learning process. The teacher needs to build up students' confidence by encouraging them to talk freely and openly in class, as recommended by Alshahrani and Alandal, (2015). An anxiety-free environment could also be implemented through the use of learners' native language. The possibility of communicating in a language that the students are proficiently familiar with would reduce their fear of expressing themselves in the classroom.

This research shall give the teachers idea to reinvent their teaching methods, especially in listening comprehension. They have to provide and prepare listening materials appropriately and at their students' own pace and rhythm. They also need to concentrate on strengthening learners' background knowledge before listening activities to give them the general idea of what they will hear. This information could help the students to predict the topics hence avoid the fear of uncertainties during the listening activity.

The study's findings may provide a better understanding of the learning anxiety to the students, parents, teachers, and the Education Ministry. It is clear that anxiety could obstruct the learning process, and something should be done to improve the French learning system in Malaysia as a whole.

\section{References}

Alpert, R., \& Haber, R. N. (1960). Anxiety in academic achievement situations. The Journal of Abnormal and Social Psychology, 61(2), 207-215. https://doi.org/10.1037/h0045464

Alshahrani, M., \& Alandal, A. (2015). An Investigation of Anxiety Among Elementary School Students Towards Foreign Language Learning. Studies in Literature and Language, 10(6), 1-11. https://doi.org/10.3968/7180

Annisa, S. R., Adnan, A., \& Marlina, L. (2020). The Relationship between Listening Anxiety and Listening Comprehension of English Department Students in Basic Listening Classes at Universitas Negeri Padang. Journal of English Language Teaching, 9(3), 510-519. https://doi.org/10.24036/jelt.v9i3.109344

Awan, R.-N., Azher, M., Anwar, M. N., \& Naz, A. (2010). An Investigation Of Foreign Language Classroom Anxiety And Its Relationship With Students Achievement. Journal of College Teaching \& Learning (TLC), 7(11), 33-40. https://doi.org/10.19030/tlc.v7i11.249

Aydın, S. (2013). Factors Affecting the Level of Test Anxiety among EFL Learners at Elementary Schools. E-International Journal of Educational Research, 4(1), 63-81. http://www.e-ijer.com/issue/8021/105377

Basco, L. M., \& Han, S.-H. (2016). Self-esteem, Motivation, and Anxiety of Korean University Students. Journal of Language Teaching and Research, 7(6), 1069. 
https://doi.org/10.17507/jltr.0706.02

Buck, G. (2001). Assessing Listening. Cambridge university press.

Cakici, D. (2016). The Correlation among EFL Learners' Test Anxiety, Foreign Language Anxiety and Language Achievement. English Language Teaching, 9(8), 190-203. https://doi.org/10.5539/elt.v9n8p190

Chand, R. K. (2007). Listening Needs of Distance Learners : A Case Study of EAP Learners at the University of the South Pacific [Doctoral dissertation, University of Otago.]. https://ourarchive.otago.ac.nz/handle/10523/201

Chang, A. C. S. (2008). Sources of listening anxiety in learning english as a foreign language. Perceptual and Motor Skills, 106(1), 21-34. https://doi.org/10.2466/PMS.106.1.21-34

Deffenbacher, J. L., Michaels, A. C., Daley, P. C., \& Michaels, T. F. (1980). A comparison of homogeneous and heterogeneous anxiety management training. Journal of Counseling Psychology, 27(6), 630-634. https://doi.org/10.1037//0022-0167.27.6.630

Dewaele, J. M. (2002). Psychological and sociodemographic correlates of communicative anxiety in L2 and L3 production. International Journal of Bilingualism, 6(1), 23-38. https://doi.org/10.1177/13670069020060010201

Dordinejad, F. G., \& Ahmadabad, R. M. (2014). Examination of the Relationship between Foreign Language Classroom Anxiety and English Achievement among Male and Female Iranian High School Students. International Journal of Language Learning and Applied Linguistics World (IJLLALW), 6 (4)(August), 446-460.

Dörnyei, Z. (2005). The Psychology of the Language Learner: Individual Differences in Second Language Acquisition (S. M. Gass, J. Schachter, \& A. Mackey (eds.)). Lawrence Erlbaum Associates, Inc.

Ebadi, F., \& Oroji, M. R. (2016). The relationship between intermediate efl learners' listening performance and listening anxiety. International Journal of Development in Social Sciences and Humanities, 2(Jul-Dec), 01-08.

https://www.ijdssh.com/past_paper.php?volid=2

Elkhafaifi, H. (2005). Listening comprehension and anxiety in the Arabic language classroom. The Modern Language Journal, 89(2), 206-220. https://doi.org/https://doi.org/10.1111/j.1540-4781.2005.00275.x

Field, J. (2009). Listening in the Language Classroom. Cambridge University Press. https://doi.org/10.1017/cbo9780511575945

Flowerdew, J. (1994). Research of relevance to second language lecture comprehension - an overview. In J. Flowerdew (Ed.), Academic Listening (pp. 7-30). Cambridge University Press. https://doi.org/10.1017/cbo9781139524612.004

Gebre, B., \& Wako, G. (2017). Relationship Between Foreign Language Listening Anxiety and Listening Comprehension. International Journal of Foreign Language Teaching \& Research, 5(19), 11-23.

Gilmore, J., \& Vance, M. (2007). Teacher ratings of children's listening difficulties. Child Language Teaching and Therapy, 23(2), 133-156. https://doi.org/10.1177/0265659007073876

Horwitz, E. K., Horwitz, M. B., \& Cope, J. (1986). Foreign Language Classroom Anxiety. The Modern Language Journal, 70, 125-132. https://doi.org/http://dx.doi.org/10.1111/j.1540-4781.1986.tb05256.x

Isrokah, S. (2016). The Correlation between Foreign Language Listening Anxiety and Listening Comprehension Achievement of the Tenth Grade Students of MAN 2 Palembang. (Skripsi). Other Thesis, UIN Raden Fatah Palembang. 
Kim, J. (2000). Foreign Language Listening Anxiety: A Study of Korean Students Learning English. Unpublished Doctoral dissertation,The University of Texas, Austin.

Kim, J. (2002). Anxiety and foreign language learning. English Teaching, 57(2), 3-34.

Liu, M. (2016). Interrelations Between Foreign Language Listening Anxiety and Strategy Use and Their Predicting Effects on Test Performance of High- and Low-Proficient Chinese University EFL Learners. Asia-Pacific Education Researcher, 25(4), 647-655. https://doi.org/10.1007/s40299-016-0294-1

Maclntyre, P. D., \& Gardner, R. C. (1989). Anxiety and Second-Language Learning: Toward a Theoretical Clarification. Language Learning, 39(2), 251-275.

https://doi.org/10.1111/j.1467-1770.1989.tb00423.x

Macintyre, P. D., \& Gardner, R. C. (1994). The Subtle Effects of Language Anxiety on Cognitive Processing in the Second Language. Language Learning, 44, 283-305. https://doi.org/http://dx.doi.org/10.1111/j.1467-1770.1994.tb01103.x

Golchi, M. (2012). Listening Anxiety and Its Relationship with Listening Strategy Use and Listening Comprehension among Iranian IELTS Learners. International Journal of English Linguistics, 2(4), 115-128. https://doi.org/10.5539/ijel.v2n4p115

Tahsildar, N. M., \& Yusoff, S. Z. (2014). Investigating L2 students' listening anxiety: A survey at a Malaysian university. International Journal of Language Education and Applied Linguistics, 1, 43-52.

Zihan, N. H. (2011). Pelaksanaan Pembelajaran Pemahaman Mendengar Dalam Kurikulum Bahasa Perancis di Sekolah Menengah di Malaysia [Doctoral dissertation, University Malaya]. http://studentsrepo.um.edu.my/3513/

Hidayati, N. A., Dewi, N. S. N., Nurhaedin, E., \& Rosmala, D. (2020). Foreign Language Listening Anxiety in an Academic Listening Class. J-SHMIC : Journal of English for Academic, 7(2), 1-9. https://doi.org/https://doi.org/10.25299/jshmic.2020.vol7(2).5241

Oteir, I., \& Abd Aziz, N. H. (2017). Effects of Listening Comprehension Anxiety from Saudi EFL Learners' Perspectives. International Journal of Linguistics, 9(5), 113-125. https://doi.org/10.5296/ijl.v9i5.11792

Pan, Y. E. (2016). Analysis of Listening Anxiety in EFL Class. International Journal on Studies in English Language and Literature, 4(6), 12-16. https://doi.org/10.20431/23473134.0406002

Razak, N. A., Yassin, A. A., \& Mohamad Maasum, T. N. R. B. T. (2017). Effect of Foreign Language Anxiety on Gender and Academic Achievement among Yemeni University EFL Students. English Language Teaching, 10(2), 73-85. https://doi.org/10.5539/elt.v10n2p73

Saeidi, M., \& Khaliliaqdam, S. (2013). The effect of socio-affective strategies on students' test anxiety across different genders. Theory and Practice in Language Studies, 3(2), 269-274. https://doi.org/10.4304/tpls.3.2.269-274

Saito, Y., Garza, T. J., \& Horwitz, E. K. (1999). Foreign language reading anxiety. The Modern Language Journal, 83(2), 202-218. https://doi.org/10.1111/0026-7902.00016

Şakrak, G. (2009). The relationship between emotional intelligence and foreign language anxiety in Turkish EFL students [Master's Thesis, Bilkent University]. http://repository.bilkent.edu.tr/handle/11693/15422\#.YDCqe1Aj5qs.mendeley

Scovel, T. (1978). The effect nf affect on Foreign Language Learning: A eview of the anxiety research. Language Learning, 28(1), 129-142.

https://doi.org/https://doi.org/10.1111/j.1467-1770.1978.tb00309.x 
Shahnaz, A., \& Bhatti, K. K. (2014). An Analysis of Relationship Between English Language Anxiety, English Language Interestand English Language Achievement. International Journal of English and Education, 3(1), 175-186.

Subekti, A. S. (2018). An exploration of learners' foreign language anxiety in the indonesian university context: Learners' and teachers' voices. Teflin Journal, 29(2), 219-244. https://doi.org/10.15639/teflinjournal.v29i2/219-244

Tosun, B. (2018). Oh no! Not ready to speak! An investigation on the major factors of foreign language classroom anxiety and the relationship between anxiety and age. Journal of Language and Linguistic Studies, 14(1), 230-241.

Vogely, A. J. (1998). Listening comprehension anxiety: Students' reported sources and solutions. Foreign Language Annals, 31(1), 67-80. https://doi.org/10.1111/j.19449720.1998.tb01333.x

Wang, S.-Y., \& Cha, K.-W. (2019). Foreign Language Listening Anxiety Factors Affecting Listening Performance of Chinese EFL Learners. The Journal of Asia TEFL, 16(1), 121134. https://doi.org/http://dx.doi.org/10.18823/asiatefl.2019.16.1.8.121

$\mathrm{Xu}, \mathrm{F}$. (2011). Anxiety in EFL listening comprehension. Theory and Practice in Language Studies, 1(12), 1709-1717. https://doi.org/10.4304/tpls.1.12.1709-1717

Yamat, H., \& Bidabadi, F. S. (2012). English language learning anxiety among iranian EFL freshman university learners. Research Journal of Applied Sciences, 7(8), 413-420. https://doi.org/10.3923/rjasci.2012.413.420

Yan, J. X., \& Horwitz, E. K. (2008). Learners' perceptions of how anxiety interacts with personal and instructional factors to influence their achievement in english: A qualitative analysis of EFL learners in China. Language Learning, 58(1), 151-183. https://doi.org/10.1111/j.1467-9922.2007.00437.x

Young, D. J. (1992). Language Anxiety from the Foreign Language Specialist's Perspective: Interviews with Krashen, Omaggio Hadley, Terrell, and Rardin. Foreign Language Annals, 25(2), 157-172. https://doi.org/10.1111/j.1944-9720.1992.tb00524.x

Zheng, Y., \& Cheng, L. (2018). How does anxiety influence language performance? From the perspectives of foreign language classroom anxiety and cognitive test anxiety. Language Testing in Asia, 8(13). https://doi.org/10.1186/s40468-018-0065-4 
Appendix

Appendix A: Malaysian DELF A1 examination mean results 2015-2019

\begin{tabular}{llllll}
\hline & $\mathbf{2 0 1 5}$ & $\mathbf{2 0 1 6}$ & $\mathbf{2 0 1 7}$ & $\mathbf{2 0 1 8}$ & $\mathbf{2 0 1 9}$ \\
\hline Reading & 17,81 & 17,96 & 16,75 & 18,35 & 18,28 \\
Writing & 18,55 & 19,82 & 18,26 & 19,92 & 17,58 \\
Listening & 13,36 & 13,94 & 13,78 & 15,99 & 15,47 \\
Speaking & 19,72 & 18,70 & 18,18 & 18,77 & 19,12 \\
\hline
\end{tabular}

Source : Alliance français de Kuala Lumpur

Appendix B: Foreign language listening anxiety questionnaire.

The questionnaire could be found in this link:

https://www.questionpro.com/a/editSurvey.do?surveylD=8075992

1= Strongly Disagree 2 = Disagree $3=$ Neutral $4=$ Agree $5=$ Strongly Agree

\begin{tabular}{|c|c|c|c|c|c|}
\hline No & Items & 1 & 2 & 3 & 4 \\
\hline 1 & $\begin{array}{l}\text { When listening to French, I tend to get stuck with one or two } \\
\text { unknown words. }\end{array}$ & & & & \\
\hline 2 & $\begin{array}{l}\text { I am nervous when I'm listening to French if I am not familiar } \\
\text { with the topic. }\end{array}$ & & & & \\
\hline 3 & $\begin{array}{l}\text { It is easy to guess about the parts that I miss while listening to } \\
\text { French. }\end{array}$ & & & & \\
\hline 4 & $\begin{array}{l}\text { If I let my mind drift even a little bit while listening to French, I } \\
\text { worry that I will miss important ideas. }\end{array}$ & & & & \\
\hline 5 & $\begin{array}{l}\text { During French listening tests, I get nervous and confused when } \\
\text { I don't understand every word. }\end{array}$ & & & & \\
\hline 6 & $\begin{array}{l}\text { I fear I have inadequate background knowledge of some topics } \\
\text { when listening in French. }\end{array}$ & & & & \\
\hline 7 & Listening to new information in French makes me uneasy. & & & & \\
\hline 8 & $\begin{array}{l}\text { I get annoyed when I come across words that I don't } \\
\text { understand while listening to French. }\end{array}$ & & & & \\
\hline 9 & $\begin{array}{l}\text { I get nervous if a listening passage is read only once during } \\
\text { listening tests. }\end{array}$ & & & & \\
\hline 10 & $\begin{array}{l}\text { When someone pronounces words differently from the way I } \\
\text { pronounce them, I find it difficult to understand. }\end{array}$ & & & & \\
\hline 11 & $\begin{array}{l}\text { When a person speaks French very fast, I worry that I might not } \\
\text { understand all of it. }\end{array}$ & & & & \\
\hline 12 & $\begin{array}{l}\text { When I am listening to French, I am worried when I can't watch } \\
\text { the lips or facial expressions of the person who is speaking. }\end{array}$ & & & & \\
\hline 13 & $\begin{array}{l}\text { When listening to French, it is difficult to differentiate the } \\
\text { words from one another }\end{array}$ & & & & \\
\hline 14 & $\begin{array}{l}\text { I feel uncomfortable in class when listening to French without } \\
\text { the written text. }\end{array}$ & & & & \\
\hline 15 & $\begin{array}{l}\text { When I'm listening to French, I usually end up translating word } \\
\text { by word without understanding the contents. }\end{array}$ & & & & \\
\hline 16 & $\begin{array}{l}\text { When listening to French I often understand the words but still } \\
\text { can't quite understand the speaker's mean. }\end{array}$ & & & & \\
\hline
\end{tabular}




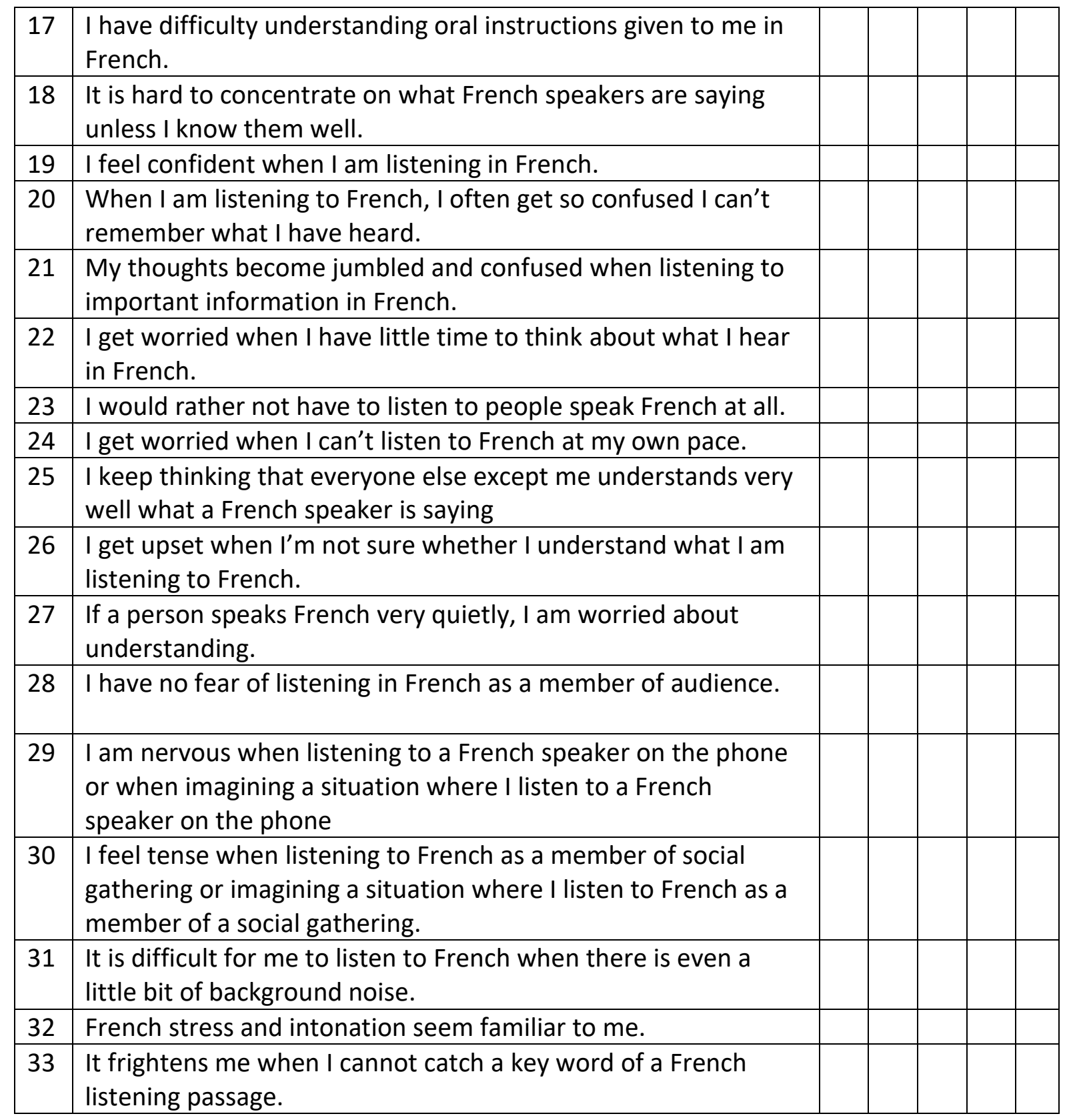

